\title{
The Utilization of Population Data House for Development Programs Intervention of Family Planning Village
}

\author{
Theodora Pandjaitan \\ Theodora Pandjaitan, Widyaiswara of Main Expert, Center of Education and Training of KKB BKKBN
}

\begin{abstract}
This study aim was to identify the Population Data House in Family Planning Village at Wilayut Village, Sukodono District, Sidoarjo Regency, East Java, as an innovative model to use population data for intervention in development of Family Planning Village. This research uses descriptive research method with a qualitative approach. The key informants were two people who aware the implementation of Population Data House program, namely an employee of East Java BKKBN and PLKB of Wilayut Village. The main informant consisted of three Wilayut Village community leaders and two Wilayut Village community members who knew the Population Data House program exactly. Data collection was done by literature study, in-depth interviews and field observations. The field were analyzed qualitatively. The results showed that implementation of Population Data House Program in Family Planning Village did not run as expected. This was seen from program implementation that did not develop from various aspects, including resources and relations between sectors. It should find a solution by implementer of Family Planning village program to develop the Population Data House program through increasing the availability of human resources, funds, and facilities as well as improving relations between sectors. Index Terms:Data House, Family Planning Village, Human Resource, Innovation, Intervention, Model, Population
\end{abstract}

DOI: $10.7176 /$ RHSS/10-4-06

Publication date: February $29^{\text {th }} 2020$

\section{Introduction}

The population should become attention center in development and the process must benefit for all parties (Adioetomo, 2010). The poverty problem, vulnerable groups and higher unemployment should become major attention to avoid instability and negative effects, such as loosening of social ties and weakening of values and relations between people (Andrew et al., 1999). Therefore, commitment to promote the economic growth fairly and without excluding the poor, increases social cohesion with politics based on human rights, non-discrimination and protection to less fortunate are the essence of population-centered development paradigm (Adioetomo, 2005)

The population is basic capital for development. It is main pillar to realize the population-oriented development (Ananta, 2013). Society participation in Population Program, Family Planning and Family Development Program is a very important (Bappenas, BPS and UNFPA, 2013). Article 58 of Law Number 52 year 2009 stated that "Every resident has the opportunity to participate in population management and family development. Such participation is done by individuals, non-governmental organizations, social organizations, professional organizations and private parties." The elucidation of Law number 52 year 2009 is realized into Population Program, Family Planning and Family Development Program as a contribution to support $5^{\text {th }}$ priority agenda of Nawacita namely improving the quality of human life in Indonesia (BPS, 2018).

Family Planning Village become a miniature model to implement Population Program, Family Planning and Family Development. It involves all fields in BKKBN environment and synergizes with Ministries / Institutions, work partners and stakeholders of relevant agencies in accordance with region needs and conditions at lowest level of government, in according to prerequisites to determine location of Family Planning Village, in all districts and cities in Indonesia (Directorate of Field Development, 2016).

The Family Planning Village is a unit at Village level with certain criteria to integrate the Population Program, Family Planning and Family Development (KKBPK) with related development sector to improve the life quality of families and communities. President of Indonesia (Ir. Joko Widodo) announced Family Planning Villages in January 2016. It has grown rapidly and the numbers were 14,000. The success of Family Planning Village is measured with series indicators. The success cannot be measured only by its results, because Family Planning Village is a series of activities including Input, Process and Output. Based on above description, this study aim is to identify the Population Data House in Family Planning Village at Wilayut Village, Sukodono District, Sidoarjo Regency, Indonesia, as an innovative model to use population data for intervention in development of Family Planning.

\section{LITERATURE REVIEW}

\subsection{Innovation}

Indonesian's Big Dictionary explains innovation as the introduction of new things, renewals, new discoveries that are different from the existing one or known before. Another opinion said that innovation is any activity that cannot 
be generated with one hit, but rather a long and cumulative process, covering many decision-making processes, from ideas discovery to the implementation in market (Kuniyoshi, 1988).

Innovation is a development and implementation of new ideas by people within a certain period of time with various transaction activities within a particular organizational structure (Van de Ven, Andrew, 1999). Rogers (2003) said that innovation is an idea, object, and practice based on and accepted as something new by a person or certain group to be applied or adopted. Stephen Robbins (2007) explained innovation as a new idea to improve the type of product or service.

\subsection{Human Resource Development}

Human resource development is learning activities held within a certain period of time in order to increase the possibility to improve performance (Nadler, 2014). Hasibuan (2014: 69) added that human resource development is an effort to improve the technical, theoretical, conceptual, and moral abilities of employees in accordance with needs of job / position through education and training. Armstrong (2010) explained development of human resources as forming behavior through experience.

Human resources development is the process to improve employees' conceptual, technical and morale. This human resources development can be done through formal education (schools), non-formal education (courses, training, upgrading) and informal education (self-taught, self-study, work experience, etc.). This human resources development uses planning and direction to put human resources in a more appropriate position based on the needs.

Human resource development is a proces to develop human resources through formal education, training and empowerment to improve the performance of human resources, which in turn can improve organizational performance.

\subsection{Family Planning Village}

Law number 5 year 1979 on Village Government defined Village as an area occupied by a number of residents as a society unit, including society and legal units in lowest governmental organization directly under the sub-district head and are entitled to hold their own households within Unitary Republic of Indonesia. Law number 22 year 1999 on Regional Government defined Village as a legal society unit with the authority to regulate and manage the interests of local society based on local origins and customs recognized in National government system and within Regency area.

Law number 72 year 2005 on the Village stated that Village is a legal society unit with territorial boundaries and authorized to regulate and administer the interests of local society, based on local origins and customs that are recognized and respected in Government system of Unitary State of Republic of Indonesia. Above definitions reflect that a village is a place for a group of people who live in lowest administrative area of government and have the right to be maintained by government.

\subsection{Population Data Houses}

The Population Data House is a Innovation to use Population Data for various development programs in Family Planning Village. Population Data House will provide accurate and updated data and information about population that can be accessed by various development sectors (Firmansyah, 2018).

The Population Data House represent Family Planning Village. It contains all information about the condition of area and population. The procedure to get data can be explained below.

a. Primary Data is. This data is collected by cadres from the field

b. Secondary Data. This is collected from research results or archieve from an agency / local government

\subsection{Conceptual Framework}

Data of Family Planning Village is collected in Population Data House. The concept of Population Data House in Family Planning Village is shown in figure 1. 


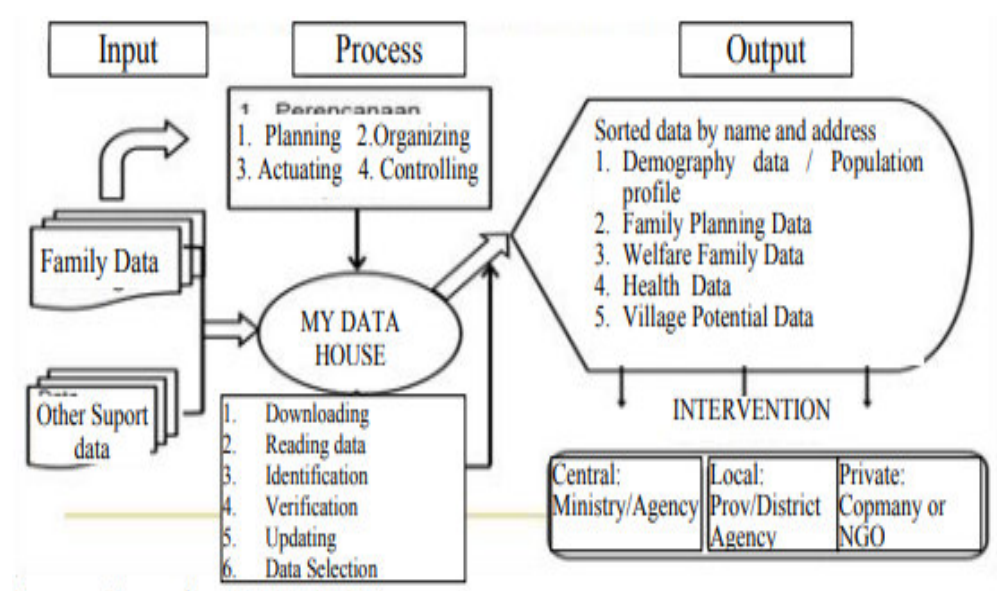

Source: Secondary Data, 2018

Figure 1. Input and Output of Population Data

The Population Data House contain data for Population Program, Family Planning and Development and other development programs related to health, education, economy needed, infrastructure and other. The data is processed into information and plan for society itself or government and regional governments.

\section{RESEARCH METHODS}

\subsection{Research Location and Time}

This is a qualitative research type. Researcher make direct observation in Family Planning Village at Wilayut Village, Sukodono District, Sidoarjo Regency, Indonesia. This research is conducted in October to November 2018.

\subsection{Research design}

This is descriptive research type to describe a situation and the stages of the development. The research method used is qualitative (Moleong, 2002: 90). Informants are individuals who have various positions and access to information in accordance with research needs (Sutopo, 2002: 50).

\subsection{Data Collection Method}

The data collection is done following methods.

1. Literature Study is used to ccolect data data or information on review of books, journals, other written works and internet.

2. Field Study is used to collect data or information directly from research location. The research instruments are observation, interviews and documentation.

There are three informants group of this research.

1. Key informants are East Java BKKBN personnel and Family Planning Village Officers at Wilayut Village.

2. The main informants are Head of Wilayut Village, Head of Family Planning Village, and Population Data House Manager.

3. Additional informants are the society and society leaders in Wilayut Village.

\subsection{Data analysis}

The collected data is analyzed by a qualitative method. Analysis is started from all available data at various data sources. The data is studied, analyzed and compiled in a unit. The next steps are categorization and checking the validity of data. Analysis is done to to make conclusions (Moleong, 2006: 247).

\section{RESEARCH RESULTS}

\subsection{General description of Wilayut Village}

Wilayut Village is an area with 108,268 Ha wide, located at altitude of 7 meters above sea level. Wilayut Village consists of two hamlets, namely: Wilayut Hamlet and Klagen Hamlet, and consist of 4 Neighborhood Groups and 17 Household Pillars. The total population of Wilayut Village is 2,961 people, male residents are 1,495 and female residents are 1,469. Total 987 heads of households $(66.9 \%)$ are poor, rich people only 10 percent, while the rest are residents with moderate economic conditions.

\subsection{Family Planning Village}

Wilayut Village is declared as Family Planning Village on Tuesday, November $14^{\text {th }}, 2017$ by Sidoarjo Regent, Mr. Saifullah. He said that Family Planning Villages is needed in Indonesia. He party wants to repeat target 
achievement as last year, "This year is also expected can achieve the target again," he added. The results of new Family Planning achievement in Sidoarjo Regency are inseparable from important role of field briefing officers of Family Planning.

The Family Planning Village data is collected to 2 key informants of Coordination Board of National Family Planning (BKKBN) and Field Officer of Family Planning (PLKB), 2 main informants namely the Wilayut Village Head, Chairman of Family Planning Village and Population Data House Manager, as well as one additional informant, Village Society Figure and Wilayut Village Society who directly felt the implementation of Family Planning Village. Mrs.Puji is an East Java BKKBN employee who very knowledgeable about the Population Data House program in Family Planning Village. Below is Mrs. Puji explanation on Population Data House.

"Population Data House has functions as a database, information center and development intervention at micro level of Family Planning Village area. The Population Data House is then introduced to wider society as the "My House my Data" to have enormous urgency and benefit for society in Family Planning Village. It can strengthen Population Family Planning and Family Development (KKBPK) program in Family Planning Village along with other development program interventions needs a basis, namely data and facts. "

The program implementation should have a legal basis. The researcher asks Mrs. Puji about the legal basis for the implementation of Family Planning Village program. Her narrative is below.

"The legal basis of Family Planning Village is Law Number 52 Year 2009 on Population Development and Family Development as the basis for implementation of Population and Family Planning Program under policy the authority of Coordination Board of National Family Planning (BKKBN) to not to focus solely on Population Control issue but the Family development problem must also get attention. In addition, the declaration of Family Planning Village in Wilayut Village refers to Domestic Minister Letter number: 440/70 / SJ dated January 11, 2016 on the declaration and Establishment of Family Planning Village ".

The researcher asks Mrs.Puji about the benefits and urgency of Population Data House. She explains below.

"First, one of mandatory prerequisites to develop a Family Planning Village is the availability of accurate population data and information. Second, Family Planning Village is created with aim to improve the life quality of society through the KKBPK program and other related sector development in order to create high quality small families. It needs up-to-date, accurate and reliable data as a basis for development planning and policy as well as a measurement tool to assess the programs achieved in Family Planning Village. Third, Family Planning Village also aims to increase the participation of government, non-governmental and private institutions in facilitating, assisting and fostering the society to organize the KKBPK program and development of related sectors.

The researcher then asks the data types are available at Population Data House. The description of Mrs.Puji is below.

"First is the Data of Family Survey and Routine Statistics BKKBN, second is the Potential Data / Village Profiles, third is Sector data, such as data needed by sectors: Health, Education, Social, Economic, Agriculture, and others; as well as family planning activity data, such as: Integrated Service, Toddler Family Development (BKB), Youth Family Development (BKR), Elderly Family Development (BKL), Efforts to Increase Welfare Family Income (UPPKS), Information Center and Youth Counselling (PIKR) and others.

Next, researcher asks Mrs.Puji on the mechanism of data management in Population Data House in Family Planning Village. Her narrative is below.

"There are a job division for administrators, chairpersons, secretaries, and data collection sections, data processing sections and data presentation sections. The data is presented in aggregate, while individual data by name by address is available in computer. This data can be downloaded by application, so it can be used as needed."

Next the researcher asks how the stages to build the Population Data House in Family Planning Village. Her narrative is below.

"The first stage is to build commitment. The establishment of Population Data House needs supports. The second stage is agreement on place to prepare the regional profile that determined as the Population Data House. The third stage is the process to determine the person responsible to manage Population Data Houses. The next stage after the process of determining and inauguration of Population Data Houses is the provision of data and information ".

Addition data is collected from interview with Mr.Agus Widodo, a Family Planning Field Officer (PLKB) who functionally fostered the Family Planning Village in Wilayut Village. Mr.Agus Widodo really knows how to implement the Family Planning Village program in Wilayut Village. His narrative is below..

"I have been a PLKB for a long time in this Wilayut Village. It has been decades since the declaration of Family Planning Village. I have been active with people here and people in Wilayut have known me. The Wilayut Village society really need empowerment, especially this Family Planning Village program. I my self know the people can lagging behind in terms of economy, education, health, welfare and so on.

The researcher asks about the human resources to implement the Family Planning Village program in Wilayut 
Village. His narrative is below.

"The human resources to implement Family Planning Village are adequate. There is a person in charge, there is a chairman and there are administrators. The village head herself becomes the chairperson, so all officials are active."

The researcher asks about the budget to support the implementation of Family Planning Village program in Wilayut Village. His narrative is below.

"The budged is given at start up for launching, construction of gate and socialization of provincial BKKBN with amount of IDR 20 million. Furthermore, IDR 100,000 is given for counselling activities consumption and transportation budget for head of PPKBD office and 50 thousand for sub-PPKBD, sourced from APBD budget, and also supported assisted by ADD ".

The program implementation has obstacles. Researcher asks the obstacles to manage Population Data House of Family Planning in Wilayut Village. His narrative is below.

"The main obstacle is operational costs. The Operational Fund for Family Planning (BOKB ) at Village operations are very small. Another obstacle is that Population Data House does not only function to store and presenting data. We want it becomes an intervention center and the people need additional skills".

The researcher asks the efforts to overcome these obstacles. His narrative is below.

"Village Head and other officers are trying to set aside funds from sale of traditional beverage products from Family Planning Village and even the fund from Village Head."

The researcher interviews Mr. Erwin who arrived at an informal meeting when the researcher visited the Wilayut Village. The researcher asks him about the meaning and benefits of Family Planning Village program in Wilayut Village. His explanation is below.

"The Family Planning Village program is intended to help people from backwardness. I am told by BKKBN of East Java province that Family Planning Village program is not only for Family Planning program, but also Population, Family Planning and Family Development program must be completed. "

The researcher interviews Mrs. Elok Agustin about the Family Planning Village of Wilayut Village. Her explanation is below.

"The Wilayut Village Family Planning Village is a Pilot Project. The program is managed by society itself while the government only become supporters. This program is originally announced by President Jokowi to strengthen the Population, Family Planning and Family Development (KKBPK) program. Family planning is one main programs of PKK, so the Family Planning Village program is the responsibility of PKK as well. I see that Family Planning Village program is very beneficial for Wilayut Village society, because the Wilayut Village society receives special attention. The Family Planning Village at Wilayut Village is inaugurated by Regent himself. below.

Then the researcher asks to Mrs. Elok abut any benefits felt of Family Planning Village. Her explanation is

"The family planning program at Wilayut Village is getting better, almost all couples of fertile age actively participate in Family Planning, namely 70 percent more couples of childbearing age have joined the family planning program. Before there is a family planning program, less than 50 percent participated in family planning program."

Mrs. Niswatul is a housewife who is involved as the organizer of Family Planning Village at Wilayut Village, namely as the Chairperson of Working Group for Population Control. The researcher asks Niswatul the management of Population Data House? He said below.

"Anyone who has had time can collect data or update existing data, especially data on results of family data collection in 2015. There is also the task to take data on village potential and taking data from Health Service Center. Then, with guidance of our Family Planning Village staff, we processed the data and made a presentation on wall of room. "

The researcher asks Mrs. Niswatul the obstacles or problems in managing the Population Data House. He says below.

"We should have a lot of skills, ranging from how to group data, create graphics. We have to wait for Family Planning staff to come to help, so that sometimes the data accumulates and is not processed. Second, cadres who are supposed to update the data are busy with their household affairs, so the data cannot be collected. Third, there is no fund, especially to process data. "

Mr.Faisal is one leaders and elders at Wilayut Village. Researchers also ask him about his knowledge of Family Planning Village program in Wilayut Village. He says below.

"In my opinion, Family Planning Village program is essential to empower the society, welfare of society's family through coaching, and as a program to improve the society in Family Planning Program. But in my opinion development of Family Planning Village program in village of Wilayut has not been very visible yet. But the family planning, Integrated Service, and other activities might still be quite good, there is people participation". 
The researcher asks Mr. Faisal's response to Family Planning Village program in Wilayut Village. His explanation is below.

"My response is certainly positive, this is good for Wilayut Village, yes, and we certainly support it. If needed, I also help to run the Family Planning Village Program".

\section{DISCUSSION}

The implementation of innovation concept is based on "Model". Research at Population Data House is a Model innovation of Population Data Utilization for intervention purpose in development program of Family Planning Village. The explanations below show the analysis related to existence of Population Data House in Family Planning Village, Role of Population Data House in operation of Family Planning Village, Utilization of Population Data House by village officials and society as a basis to intervene simple population problems, and benefits of Population Data House for related sector.

1. Identification of Population Data Houses in Family Planning Village operations.

The Family Planning Village is formed with aim to improve the life quality of society at village level or equivalent through the KKBPK program and development of other related sectors in order to realize high quality of small families. Therefore, it needs updated data, accurate and trusted to become basis for planning and development policy and as a measurement tool to assess the success achieved in Family Planning Village. The existence of Family Planning Village is also expected to increase the participation of government, nongovernmental and private institutions in facilitating, assisting and fostering the society to organize the KKBPK program.

2. Role of Population Data Houses in the Operations of Family Planning Village

The response of implementers as the PLKB and also the Cadre of Family Planning Village program in Wilayut Village are very well with existence of Family Planning Village program. This Family Planning Village will later prosper the people of Wilayut Village. The implementation of Family Planning Village program is good. The officers run the Family Planning Village program. They really understand the program and its implementation.

3. Utilization of Population Data Houses by Village Officials and society as a basis to intervene the simple population problems.

The Population Data House basically has function not only as a data center, but also as an intervention center for population problems. In essence, it covers the management and system utilization of population data at micro level, starting from identifying, collecting, verifying, and utilizing population data sourced from, by, and for society.

The participation of society in population management and family development has been mandated in Law No. 52 year 2009 on Population and Family Development Article 58 which states that "Every resident has the opportunity to participate in management of population and family development. The role is done by individuals, non-governmental organizations, social organizations, professional organizations and private parties.

4. Population Data House gives benefit to relevant sector in developing the society of Family Planning at Wilayut Village.

The Population Data House basically is formed to improve data governance, especially in village. It is integrated with other data sources, such as sectoral data collected by various institutions. The quality of data will be better, because the data is collected from society, by society and for society.

The Population Data House has been established for a year. The immunization program by local Health Office uses records taken from Population Data House. Because the list of children under five year is available individually and clearly recorded (by name by address), coverage of immunization services is 100 percent successful.

\section{CONCLUSION AND SUGGESTION}

The conclusion of this research can be stated below.

1. Population Data House has technical manual for implementation, from beginning of activity to final stage, namely the report and also the program evaluation.

2. Implementation of Population Data Houses in Family Planning Village requires the availability of resources.

3. The Family Planning Village in Wilayut village has been communicate the data to PKB / PLKB, Cadre, TOGA, TOMA, and also related SKPD.

Based on above conclusions, the suggestions can be stated below.

1. Population Data House should be repositioned in accordance with technical instructions provided.

2. Trained management officers should be added to provide adequate service.

3. Cooperation should be improved to all elements of development programs for society welfare in Family Planning Village. 


\section{REFERENCES}

Adioetomo, S. M. (2010). Dasar-dasar Demografi, Lembaga demografi FE UI, Jakarta, 2010.

Adioetomo, S. M. (2005). Bonus Demografi: Hubungan antara Pertumbuhan Penduduk dengan Pertumbuhan Ekonomi, Jakarta: BKKBN.

Ananta, A. (2013). Paparan Analisis Demografi dalam Perencanaan Pekerjaan, Program Pascasarjana UI.

Andrew, V, Douglas P., Raghu G., and Venkataraman S. (1999). The Innovation Journey. New York: Oxford University Press.

Amstrong, M. (2010). ManajemenSumberDayaManusia. PT Elexmedia. Komputindo. Jakarta.

Bappenas, BPS dan UNFPA. (2013). Proyeksi Penduduk Indonesia Periode 2010-2035, Jakarta: BPS.

Badan Pusat Statistik (BPS, Badan Kependudukan dan Keluarga Berencana Nasional (BKKBN), dan Kementerian Kesehatan. (2018). Survei Demografi dan Kesehatan Indonesia 2017, Jakarta.

Direktorat Bina Lini Lapangan.(2016). Pedoman Pelaksanaan Kegiatan Integrasi Kampung KB Bersama Mitra Kerja, BKKBN, Jakarta.

Everett M. R. (2018). Diffusion of Innovations, Fifth Edition, Free Press, New York, 2003.

Firmansyah, https://www.nesabamedia.com/Pengertian Data BesertaFungsi Data danJenis-jenis Data yang WajibAndaKetahui, accessed at 2 November 2018.

Hasibuan, M. (2014). ManajemenSumberDayaManusia. Jakarta: Bumi. Aksara.

Kuniyoshi U. (1998). Innovation and Management, De Gruyter, Berlin, Germany, 1988.

Moleong, L. (2002). Metodologi Penelitian Kualitatif. PT. Remaja Rosda Karya, Bandung, 2002.

Nadler, J. T., \& Kufahl, K. M. (2014). Marital Status , Gender , And Sexual Orientation: Implications For Employment Hiring Decisions, 1(3), 270-278.

Stephen P. R. (2007). Management, ninth edition, Chapter 13, Managing Change and Innovation, Prentice Hall. Inc.

Sugianto. (2015). Modul Kebijakan Program Kependudukan, Keluarga Berencana dan Pembangunan Keluarga, Pusdiklat Kependudukan dan Keluarga Berencana-BKKBN, 2015.

Sugiyono. (2016). Metodologi Penelitian Kuantitatif Kualitatif dan R \& D, Alfabeta, Bandung, 2006.

Tjahjo Kumolo dan Tim. (2014). Nawa Cita untuk Kesejahteraan Rakyat Indonesia, Integrasi Pembangunan Nasional dan Daerah. Jakarta : Buku Kompas.

Undang-Undang Republik Indonesia Nomor 5 Tahun 1979 tentang Pemerintahan Desa, www.hukumonline.com, accessed at 15 November 2018.

Undang-Undang Nomor 22 Tahun 1999 tentang Pemerintahan Daerah, http://www.djpk.kemenkeu.go.id/?p=339, accessed at 15 November 2018

Undang-UndangRepublik Indonesia Nomor 72 Tahun 2005 tentang Desa, http://www.bphn.go.id, accessed at 12 Desember 2018.

Undang-Undang Republik Indonesia Nomor 52 Tahun 2009 tentang Perkembangan Kependudukan dan Pembangunan Keluarga, accessed at 112 Desember 2018.

http://referensi.elsam.or.id/2014/10/uu-nomor-52-tahun-2009-tentang-perkembangan-kependudukan-danpembangunan-keluarga/.

https://bukubiruku/metode-penelitian-kualitatif, MetodologiPenelitianKualitatifdanContoh Proposal,accessed at 11 Desember 2018.

http://stormharven.blogspot.co.id/2013/05/pembangunan-berwawasan-kependudukan.html, accessed at 11 December 2018. 